\title{
Evaluation of neonatal admission to neonatal intensive care unit in a tertiary care hospital in Kashmir
}

\author{
Rehana Rashid ${ }^{1 *}$, Muddasser Nazir' ${ }^{1}$, Javid Ahmed Sofi²
}

\begin{abstract}
${ }^{1}$ Department of Obstetrics and Gynecology, Government Medical College, Srinagar, Jammu and Kashmir, India ${ }^{2}$ Department of Medicine, Sheri Kashmir Institute of Medical Sciences, Srinagar, Jammu and Kashmir, India
\end{abstract}

Received: 14 December 2021

Revised: 09 January 2022

Accepted: 11 January 2022

\author{
*Correspondence: \\ Dr. Rehana Rashid, \\ E-mail: rehanarashid123@gmail.com
}

Copyright: (C) the author(s), publisher and licensee Medip Academy. This is an open-access article distributed under the terms of the Creative Commons Attribution Non-Commercial License, which permits unrestricted non-commercial use, distribution, and reproduction in any medium, provided the original work is properly cited.

\section{ABSTRACT}

Background: Neonatal period is the most unguarded period which influences the survival and overall wellbeing of a child. Many illnesses affecting the neonates lead to morbidities and mortality among them. According to 2015 Global health observatory $(\mathrm{GHO})$ data, neonatal deaths constitute roughly $45 \%$ of all under five deaths. Worldwide, neonatal mortality rate has seen a steady decline by $47 \%$ between 1990 and 2015 from 36 to 19 per 1000 live birth. India contributes to nearly $25 \%$ of the mortality around the world.

Methods: This descriptive retrospective study was carried out at LallaDed hospital, only tertiary care obstetrics and gynaecology hospital of Kashmir valley from August 2020 to January 2021. The study was conducted with records of the neonates who were admitted to NICU of this hospital during the above mentioned time period. The data regarding gestational age, sex, mode of delivery, birth weight, Apgar score at birth, indication for admission and outcome was recorded.

Results: The total number of NICU admission during this time period was 252 . The mode of delivery was FTVD in $144(57.1 \%)$ and LSCS in $108(42.9 \%)$. The number of preterm babies was $175(69.4 \%)$ and number of term babies was $77(30.6 \%)$. Among the admitted neonates, $141(56 \%)$ were male and $111(44 \%)$ were female babies. The birth Apgar score 0 minutes was 8 in 24, 7 in 75, 6 in 130 and 4 in 23 babies.

Conclusions: This study identified RDS and MAS among the most common reasons for NICU admission. Early neonatal period is the major contributor to neonatal mortality which is influenced by birth weight and Apgar score. Understanding causes of neonatal mortality, education and training of medical and para medical staff and implementation of interventions regarding neonatal resuscitation will play major role in decreasing the neonatal NICU admission and mortality thereof.

Keywords: NICU, Apgar score, Newborn

\section{INTRODUCTION}

Neonatal period is the most unguarded period which influences the survival and overall wellbeing of a child. ${ }^{1}$ Many illnesses affecting the neonates lead to morbidities and mortality among them. According to 2015 GHO data, neonatal deaths constitute roughly $45 \%$ of all under five deaths. ${ }^{2}$ Worldwide, neonatal mortality rate has seen a steady decline by $47 \%$ between 1990 and 2015 from 36 to
19 per 1000 live birth. ${ }^{2}$ India contributes to nearly $25 \%$ of the mortality around the world. ${ }^{3-5}$ Major causes of neonatal deaths are preterm birth, asphyxia, sepsis, pneumonia, congenital anomalies, diarrheal diseases and tetanus. ${ }^{6}$ The most routinely used measure of health status of newborns is the Apgar score, typically quantified at 7, 5 and 10 minutes after birth. ${ }^{7}$ It is widely recognised that a low Apgar score, commonly defined as a score less than 7 , is associated with increased risks of neonatal mortality, 
morbidity and long term outcomes. ${ }^{8-16}$ The challenge ahead of us was to meet every newborn target of ten or fewer neonatal deaths per 1000 live births in every country by 2035. ${ }^{17}$ Without a sound knowledge about the changing trends in morbidity and mortality, it will be difficult to formulate appropriate strategies in management, prevention and review. ${ }^{18}$

\section{Aim and objective}

The aim and objective was to analyse and evaluate the neonatal NICU admission in tertiary care hospital in Kashmir.

\section{METHODS}

This descriptive retrospective study was carried out at LallaDed hospital, only tertiary care obstetrics and gynaecology hospital of Kashmir valley from August 2020 to January 2021.

The study was conducted with records of the neonates who were admitted to NICU of this hospital during the above mentioned time period.

The data regarding gestational age, sex, mode of delivery, birth weight, Apgar score at birth, indication for admission and outcome was recorded.

\section{Statistical analysis}

The data obtained were analysed using descriptive statistics.

\section{Ethical approval}

The study was approved by the institutional ethics committee.

\section{RESULTS}

Total number of deliveries during this time period was 8508, with 5400 LSCS and 3108 NVDS. The total number of NICU admission during this time period was 252. The mode of delivery was FTVD in $144(57.1 \%)$ and LSCS in $108(42.9 \%)$.

Table 1: Mode of delivery.

\begin{tabular}{|lll|}
\hline Mode & Frequency & Percent \\
\hline FTVD & 144 & 57.1 \\
\hline LSCS & 108 & 42.9 \\
\hline Total & 252 & 100.0 \\
\hline
\end{tabular}

The number of preterm babies was $175(69.4 \%)$ and number of term babies was 77 (30.6\%).

Among the admitted neonates, $141(56 \%)$ were male and $111(44 \%)$ were female babies.
Table 2: Gestation age.

\begin{tabular}{|lll|}
\hline Gestation age & Frequency & Percent \\
\hline Preterm & 175 & 69.4 \\
\hline Term & 77 & 30.6 \\
\hline Total & 252 & 100.0 \\
\hline
\end{tabular}

Table 3: Birth Apgar.

\begin{tabular}{|lll|}
\hline Score & Frequency & Percent \\
\hline $\mathbf{4}$ & 23 & 9.1 \\
\hline $\mathbf{6}$ & 130 & 51.6 \\
\hline $\mathbf{7}$ & 75 & 29.8 \\
\hline $\mathbf{8}$ & 24 & 9.5 \\
\hline Total & 252 & 100.0 \\
\hline
\end{tabular}

Table 4: Indication of NICU admission.

\begin{tabular}{|lll|}
\hline Indications & Frequency & Percent \\
\hline RDS & 80 & 31.74 \\
\hline MAS & 46 & 18.25 \\
\hline Birth asphyxia & 37 & 14.68 \\
\hline LBW & 19 & 7.54 \\
\hline Hypoglycemia & 17 & 6.35 \\
\hline Septic shock & 16 & 6.35 \\
\hline Syndromic baby & 16 & 6.35 \\
\hline Seizures & 10 & 3.97 \\
\hline CCF & 8 & 3.20 \\
\hline ICH & 3 & 1.19 \\
\hline Total & 252 & 100 \\
\hline
\end{tabular}

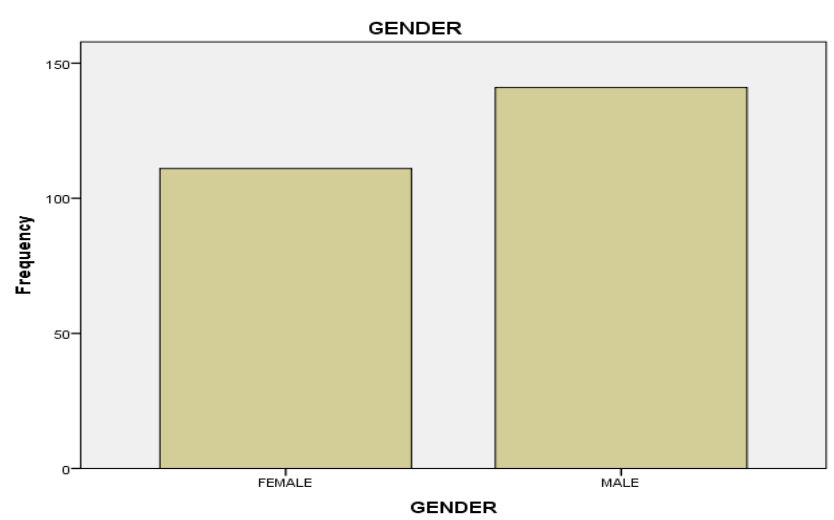

Figure 1: Gender distributions.

The birth Apgar score 0 minutes was 8 in 24, 7 in 75, 6 in 130 and 4 in 23 babies.

The mean birth weight of admitted babies was $2.30 \mathrm{kgs}$. The most common indication for NICU admission was RDS (31.74\%), meconium aspiration syndrome (18.25\%), birth asphyxia (14.68\%), LBW $(7.54 \%)$, hypoglycemia $(6.75 \%)$, septic shock $(6.35 \%)$, syndromic babies $(6.35 \%)$, seizure disorder $(3.97 \%)$, CCF $(3.2 \%)$ and ICH $(1.19 \%)$. Out of 252 admitted babies, $203(80.6 \%)$ babies were 
stable and $44(17.5 \%)$ babies expired and $5(2 \%)$ babies were shifted to other hospital.

\section{DISCUSSION}

This study was conducted to evaluate the reasons for neonatal admission to NICU and the morbidity and mortality pattern in the tertiary care hospital in Kashmir. This study was carried out from August 2020 to January 2021 at Government LallaDed hospital Srinagar. Total number of deliveries during this time period was 8508 , with 5400 LSCS and 3108 NVDS. The total number of NICU admission during this time period was 252. The mode of delivery was FTVD in $144(57.1 \%)$ and LSCS in 108 (42.9\%). The number of preterm babies among admitted neonates was $175(69.4 \%)$ and number of term babies was $77(30.6 \%)$. This was in line with the findings from study conducted by Modi et al. ${ }^{1}$ There was male predominance with respect to NICU admissions. Similar findings were reported by several studies. ${ }^{1,19-23}$ The birth Apgar score at 0 minutes was 8 in 24.7 in 75.6 in 130 and 4 in 23 babies. The mean birth weight of admitted babies was $2.30 \mathrm{kgs}$. Worldwide, prematurity, sepsis and birth asphyxia were the leading causes of death among neonates. ${ }^{24}$ The most common indication for NICU admission in our study was RDS (31.74\%) followed by meconium aspiration syndrome $(18.25 \%)$, birth asphyxia (14.68\%) and LBW (7.54\%.) Out of 252 admitted babies, $203(80.6 \%)$ babies were stable and $44(17.5 \%)$ babies expired and 5 (2\%) babies were shifted to other hospital. This successful discharge and lower mortality rates were in contrast to the study done by Gauchan et al. ${ }^{25}$

\section{Limitations}

The limitations of the study was the data was not representative of the community as it was hospital based study, still born cases were not taken into the consideration.

\section{CONCLUSION}

Neonatal mortality is an indicator of health status of the community. This study identified RDS and MAS among the most common reasons for NICU admission. Early neonatal period is the major contributor to neonatal mortality which is influenced by birth weight and APGAR score. Understanding causes of neonatal mortality, education and training of medical and para medical staff and implementation of interventions regarding neonatal resuscitation will play major role in decreasing the neonatal NICU admission and mortality thereof.

\section{Funding: No funding sources}

Conflict of interest: None declared

Ethical approval: The study was approved by the Institutional Ethics Committee

\section{REFERENCES}

1. Modi R, Modi B, Patl JK, Punitha KM. Study of the morbidity and the mortality pattern in the nonatal intensive care unit at a tertiary care teaching hospital in Gandhinagar District, Gujarat, India. J Res Med Den Sci. 2015;3:208-12.

2. WHO. Fact sheet: Global Health Observatory (GHO) data. Available at: http://www.who.int/gho/en/. Accessed on 1 December 2021.

3. Manhas S. A critical analysis of childhood morbidity and mortality pattern in india: trends and disparities. Asian J Sci Tecnol. 2016;7:2912-8.

4. Roy KK, Baruah J, Kumar S, Malhotra N, Deorari AK, Sharma JB. Maternal antenatal profile and immediate neonatal outcome in VLBW and ELBW babies. Indian J Pediatr. 2006;73(8):31-5.

5. Sangamam R. Perinatal mortality and morbidity among low birth weight babies. Int J Commun Med Pub Health. 2015;2(1):51-8.

6. Pattinson R, Kerber K, Eckhart B, Friberg I, Belizan M, Lansky, et al. Causes of neonatal and child mortality in India: a nationally representative mortality survey. Lancet. 2010;376(9755):1853-60.

7. Apgar V. A proposal for a new method of evaluation of the newborn infant. Curr Res Anesth Analg. 1953;32(4):260-7.

8. Cnattingius S, Norman M, Granath F, Petersson G, Stephansson O, Frisell T. Apgar score components at 5 minutes: risks and prediction of neonatal mortality. Paediatr Perinat Epidemiol. 2017;31(4):328-37.

9. Thorngren-Jerneck K, Herbst A. Low 5-minute Apgar score: a population-based register study of 1 million term births. Obstet Gynecol. 2001;98(1):65-70.

10. Salustiano EMA, Campos JADB, Ibidi SM, Ruano R, Zugaib M. Low Apgar scores at 5 minutes in a low risk population: maternal and obstetrical factors and postnatal outcome. Rev Assoc Med Bras (1992). 2012;58(5):587-93.

11. Moore EA, Harris F, Laurens KR, Green MJ, Brinkman S, Lenroot RK, et al. Birth outcomes and academic achievement in childhood: A population record linkage study. J Early Child Res. 2014;12:23450 .

12. Odd DE, Rasmussen F, Gunnell D, Lewis G, Whitelaw A. A COHORT study of low Apgar scores and cognitive outcomes. Arch Dis Child Fetal Neonatal Ed. 2008;93(2):115-20.

13. Ehrenstein V, Pedersen L, Grijota M, Nielsen GL, Rothman KJ, Sørensen HT. Association of Apgar score at five minutes with longterm neurologic disability and cognitive function in a prevalence study of Danish conscripts. BMC Pregnancy Childbirth. 2009;9:14.

14. Moster D, Lie RT, Markestad T. Joint association of Apgar scores and early neonatal symptoms with minor disabilities at school age. Arch Dis Child Fetal Neonatal Ed. 2002;86(1):16-21.

15. Marschik PB, Einspieler C, Garzarolli B, Prechtl HF. Events at early development: are they associated with 
early word production and neuro developmental abilities at the preschool age? Early Hum Dev. 2007;83(2):107-14.

16. Krebs L, Langhoff-Roos J, Thorngren-Jerneck K. Long-term outcome in term breech infants with low Apgar score-a population-based follow up. Eur $\mathbf{J}$ Obstet Gynecol Reprod Biol. 2001;100(1):5-8.

17. Bhutta ZA, Das JK, Bahl R, Lawn JE, Salam RA, Paul VK, et al. Can available interventions end preventable deaths in mothers, newborn babies, and stillbirths, and at what cost? Lancet. 2014;384(9940):347-70.

18. Anish S, Sam A, Alex A, Ashitha N. Baby mortality pattern of hospitalised neonates in a tertiary care hospital in Ernakulam, May. KMJ. 2011:3.

19. Kumar MK, Thakur SN, Singh BB. Study of the morbidity and the mortality patterns in the neonatal intensive care unit at a tertiary care teaching hospital in Rohtas District, Bihar, India. J Clin Diagn Res. 2012;6:282-5.

20. Harsha PJ, Iyer CR, Rathod AD, Nagendra K, Chandan CK, Gornale VK. A prospective observational study of short term morbidity pattern in preterm newborns delivered in a tertiary care hospital. J Evidence Med Healthcare. 2015;2:5432-7.

21. Malik S, Gohiya P, Khan IA. Morbidity profile and mortality of neonates admitted in neonatal intensive care unit of a Central India teaching institute: a prospective observational study. J Clin Neonatol. 2016;5(3):168-73.

22. Baruah MN, Panyang PP. Morbidity and mortality profi le of newborns admitted to the special care newborn unit (SCNU) of a teaching hospital of upper Assam, India: a three year study. J Med Sci Clin Res. 2016;4(7):11689-95.

23. Abdellatif M, Ahmed M, Bataclan MF, Khan AA, AlBattashi A, AlManiri A. The patterns and causes of neonatal mortality at a tertiary hospital in Oman. Oman Med J. 2013;28(6):422-6.

24. WHO. Fact sheet: Newborn death and illness. Available

at: http://www.who.int/pmnch/media/press_materials/fs/ fsnewborndealthillness/en/. Accessed on 1 December 2021.

25. Gauchan E, Rao KS. Clinical profile and outcome of babies admitted to neonatal intensive care unit (NICU). J Inst Med. 2011;33(2):1-8.

Cite this article as: Rashid R, Nazir M, Sofi JA. Evaluation of neonatal admission to neonatal intensive care unit in a tertiary care hospital in Kashmir. Int J Reprod Contracept Obstet Gynecol 2022;11:527-30. 